\title{
Vitamin D levels in peanut allergic children
}

\author{
Adam Fowlie $^{1 *}$, Laura Kim ${ }^{1}$, Trefford L Simpson ${ }^{2}$, Harold Kim ${ }^{1,3}$ \\ From Canadian Society of Allergy and Clinical Immunology Annual Scientific Meeting 2011 \\ Quebec, Canada. 20-23 October 2011
}

\section{Background}

The prevalence of peanut allergy is increasing. The reasons for this are not entirely known. A factor may be vitamin D (Vit D).

\section{Methods}

This study was performed in a referral allergist's office in Ontario. Prospectively, all patients $(<18$ years old) with peanut allergy who were tested for peanut specific IgE (PN IgE) also had Vit D measured. All measurements were done between December 2010 and May 2011. The Vit D measure was 25 -hydroxy vitamin D. Patients were divided into three groups: deficient (less than $25 \mathrm{nmol} / \mathrm{L}$ ), insufficient $(25-75 \mathrm{nmol} / \mathrm{L})$ and sufficient $(75-250 \mathrm{nmol} / \mathrm{L})$. Vit D levels were compared to PN IgE, sex, age, body mass index (BMI) and other allergies.

\section{Results}

Fifty peanut allergic patients were included. The mean Vit D level of the patients was $73.8 \mathrm{nmol} / \mathrm{L}$ and the $95 \%$ confidence interval was $69.6-75.7 \mathrm{nmol} / \mathrm{L}$. One patient (2\%) had deficient and thirty-one (62\%) of the patients had insufficient Vit D levels. Nineteen (38\%) had Vit D levels in the sufficient range. There was no correlation between Vit D levels and PN IgE or BMI. Generalized linear modeling showed that vit $\mathrm{D}$ levels were predicted by age and sex $(\mathrm{p}=0.04 \& \mathrm{p}=0.002$, respectively).

\section{Conclusions}

Two percent of our patients had deficient Vit D levels while $62 \%$ of our patients had insufficient Vit D levels. These levels were statistically associated with age and sex. Insufficiency of Vit D may play a role in peanut allergy.

\section{Author details}

${ }^{1}$ University of Western Ontario, Canada. ${ }^{2}$ University of Waterloo, Canada.

${ }^{3}$ McMaster University, Canada.

${ }^{1}$ University of Western Ontario, Canada

Full list of author information is available at the end of the article
Published: 14 November 2011

doi:10.1186/1710-1492-7-S2-A8

Cite this article as: Fowlie et al:: Vitamin D levels in peanut allergic

children. Allergy, Asthma \& Clinical Immunology 2011 7(Suppl 2):A8.
Submit your next manuscript to BioMed Central and take full advantage of:

- Convenient online submission

- Thorough peer review

- No space constraints or color figure charges

- Immediate publication on acceptance

- Inclusion in PubMed, CAS, Scopus and Google Scholar

- Research which is freely available for redistribution
() Biomed Central 